\title{
PENGUASAAN BAHASA INGGRIS MAHASISWA BARU UNY TAHUN AKADEMIK 2005/2006 - 2009/2010 PADA KRITERIA TOEFL-LIKE
}

\author{
Bambang Sugeng, Suhaini M. Saleh, dan G. Suharto \\ Fakultas Bahasa dan Seni Universitas Negeri Yogyakarta \\ e-mail: ba_geng@yahoo.com
}

\begin{abstract}
Abstrak
Pertanyaan penelitian ini berkaitan dengan (1) tingkat kemahiran bahasa Inggris mahasiswa pada tingkat fakultas dan universitas, (2) tingkat kemahiran bahasa Inggris mahasiswa pada masing-masing program studi, (3) kemahiran mahasiswa dalam Listening, Structure, and Reading, dan (4) kegiatan tindak lanjut dari tes TOEFL-Like. Dengan rancangan penelitian survei, penelitian melibatkan 24.909 mahasiswa baru UNY tahun ajaran 2005-2009. Data data dianalisis secara kuantitatif menggunakan rerata, simpang baku, frekuensi, dan persentase. Hasil penelitian sebagai berikut. Pertama, pada tingkat universitas, mahasiswa memperoleh rerata 367 (tingkat intermediate) dengan simpang baku 50,65 (homogenitas tinggi). Pada tingkat fakultas, rerata FMIPA 378,81, FISE 372,83, FT 367,18, FBS 363,83, FIP 363,77, dan FIK 356,44. Kedua, skor tertinggi (400 atau lebih) dicapai oleh empat program studi, urutan kedua (375 - 399) dicapai oleh 13 program studi, urutan ketiga (350 - 374) dicapai oleh 45 program studi, dan urutan terbawah (349 atau kurang) dicapai oleh 8 program studi. Ketiga, pencapaian skor Reading 35,5\%, Structure $31,25 \%$, dan Listening 27,2\%. Keempat, kegiatan tindak lanjut yang dapat dilakukan meliputi: peningkatan skor TOEFL mahasiswa, penyelenggaraan kursus, peningkatan bahasa Inggris sebagai MKU, perencanaan dan penyelenggaraan program internasional, dan persyaratan kelulusan bagi S-1.
\end{abstract}

Kata kunci: persyaratan kelulusan, kemahiran berbahasa, penempatan, penerimaan mahasiswa, TOEFL-Like

\section{YOGYAKARTA STATE UNIVERSITY STUDENTS' ENGLISH PROFICIENCY BASED ON TOEFL-LIKE IN THE ACADEMIC YEARS OF 2005/2006-2009/2010}

\begin{abstract}
Four research questions are proposed related to (1) students' English proficiency levels at the university and faculty levels, (2) their English proficiency levels in each study program, (3) their proficiency in Listening, Structure, and Reading, and (4) possible activities as follows-ups of the TOEFL-Like tests. Using the survey research design, the study involved 24,909 YSU new students of the academic years 2005-2009. Data were analyzed quantitatively using the mean, standard deviation, frequency, and percentages. The results are as follows. First, on the university level, students attain a mean score of 367 (intermediate) with a standard deviation of 50.65 (high homogeneity). On the faculty level, they attain a mean score of 378.81 (FMIPA), 372.83 (FISE), 367.18 (FT), 363.83 (FBS), 363.77 (FIP), and 356.44 (FIK). Second, highest scores are achieved by four study programs (400 or higher), the second by 13 study programs ( $375-399)$, the third by 45 study programs $(350-374)$, and the lowest scores by eight study programs (349 or lower). Third, the score attainment is 35.5\% (Reading), 31.25\% (Structure), and 27.2\% (Listening). Fourth, possible follow-up activities are elevation of students' TOEFL scores, course placements, improvement of MKU English, planning and implementation of international programs, and graduation requirement for S-1.
\end{abstract}

Keywords: graduation requirement, language proficiency, placement, student recruitment, TOEFL-Like 


\section{PENDAHULUAN}

Mulai tahun 2005, Universitas Negeri Yogyakarta (UNY) menunjuk Fakultas Bahasa dan Seni (FBS) melalui Pusat Pelayanan dan Pengembangan Bahasa (P3B) untuk mengadakan pengukuran penguasaan bahasa Inggris mahasiswa baru dengan menggunakan TOEFL-Like sebagai alat pengukur. Sampai saat ini belum pernah dilakukan pembahasan mengenai hasil tes bahasa Inggris untuk mahasiswa baru tersebut. Penelitian ini merupakan salah satu usaha untuk melihat, menganalisis, dan mengemukakan hal-hal yang penting dan menarik dari hasil tes tersebut.

Di Indonesia, penggunaan TOEFL sebagai tes profisiensi bahasa Inggris cukup luas, dari yang sekedar untuk mengetahui kekuatan diri seseorang dalam penguasaan bahasa Inggris sampai untuk tujuantujuan penting seperti memasuki program pendidikan dan melamar pekerjaan. Di departemen dan kantor pemerintahan, TOEFL semakin banyak digunakan untuk tujuan-tujuan akreditasi, internasionalisasi, hibah bersaing, dan sebagainya. Penggunaan TOEFLuntuk mengukur profisiensi mahasiswa baru (MABA) bukanlah sesuatu yang baru. Di Universitas Negeri Yogyakarta, TOEFL MABA ini sudah dilakukan sejak tahun 2005.

Penyelenggaraan pengukuran penguasaan bahasa Inggris mahasiswa baru adalah langkah penting yang telah diambil oleh universitas. Hasil tes profisiensi dapat digunakan untuk berbagai tujuan. Yang paling sering, nilai tes profisiensi digunakan untuk tujuan penempatan. Dengan menggunakan peringkat nilai, peserta pembelajaran dapat dikelompokkan menjadi kelas-kelas pemula, menengah, dan lanjut. Hasil tes profisiensi juga dapat digunakan untuk tujuan-tujuan program remedial atau pengayaan. Peserta dengan nilai yang memadai dapat diberi program pengayaan, sedangkan peserta dengan nilai kurang dapat diberi program remedial. Bahan pembelajaran untuk program-program ini pun dapat dikembangkan berdasarkan hasil analisis butir tes. Butir-butir yang ternyata sukar bagi peserta dapat diberi perhatian lebih banyak atau lebih khusus. Programprogram lain yang dapat menggunakan hasil tes profisiensi bahasa Inggris adalah penerimaan mahasiswa baru, persyaratan untuk program-program hibah, penentuan program studi sebagai program internasional, persyaratan kelulusan S-1, dan sebagainya.

Penguasaan bahasa seseorang disebut profisiensi yang mengandung arti seberapa tinggi penguasaan bahasa seseorang pada suatu saat tertentu (Creswell, 2008; Weir, 2005). Untuk mengukur profisiensi bahasa seseorang, digunakan perangkat tes bahasa yang disebut tes penguasaan bahasa (language proficiency test). Untuk memperjelas pemahaman profisiensi bahasa, biasanya tes jenis ini dibandingkan dengan jenis tes yang lain, terutama tes prestasi language achievement test). Beberapa hal yang membedakan kedua jenis tes ini berhubungan dengan tujuan diadakannya pengukuran (testing).

Suatu tes profisiensi dikembangkan dengan berbagai tujuan. Dalam suatu program, tes profisiensi bisa langsung berhubungan dengan tujuan komunikasi bahasa, tujuan perencanaan program, dan tujuan pelaksanaan program (Departemen Pendidikan Nasional, 2009). Dalam tujuan komunikasi bahasa, tes profisiensi dapat mengungkap atau menafsirkan fungsi dan ujaran bahasa peserta tes. Dalam fungsi ini, pengambil keputusan mendapatkan informasi seberapa baik pesereta tes dapat menggunakan bahasa untuk bertutur. Dalam tujuan perencanaan, tes profisiensi dapat mengungkapkan karakter peserta tes sebagai masukan dalam suatu program. Dalam fungsi ini, pengambil keputusan menyesuaikan perlakuan (treatment) dalam suatu program dengan karakteristik peserta tes. Demikian pula, dalam fungsi pelaksanaan program, pengambil keputusan dapat menyesuaikan kegiatan- 
kegiatan dalam program dengan karakteristik peserta tes.

Salah satu tes profisiensi bahasa Inggris yang banyak digunakan di dunia adalah TOEFL (Test of English as a Foreign Language). Dari bentuknya yang konvensional dan sederhana, TOEFL telah dikembangkan sedemikian rupa sehingga menjadi instrumen pengu-jian bahasa Inggris yang termasa (ETS, 2009). Computerbased TOEFL, misalnya, merupakan salah satu contoh pengembangan TOEFL yang menggunakan teknologi komputer. Dengan Rerata 500, dan standar deviasi 100, TOEFL telah banyak diakui sebagai tes yang memiliki kesahihan dan keterhandalan yang tinggi (Tucker \& van Bemmet, 2002: 15). Lebih dari 7500 sekolah dan universitas di 130 negara menetapkan TOEFL sebagai alat pengukuran penguasaan bahasa. Sampai hari ini, lebih dari 24 juta siswa dan mahasiswa menggunakan TOEFL sebagai syarat masuk sekolah. TOEFL diadakan di lebih dari 4.500 tempat di 165 negara (Elets Technomedia, 2010). Salah satu dari berbagai penelitian mengenai TOEFL menunjukkan perbedaan signifikan dalam hal hasil belajar antara mahasiswa yang bernilai TOEFL tinggi (550 atau lebih) dengan mahasiswa yang bernilai TOEFL rendah (Kurang dari 550), terutama pada semester atau kuartal pertama tahun akademik. Ini menunjukkan bahwa tes profisiensi bahasa Inggris dapat dijadikan sebagai alat prediksi untuk keberhasilan studi mahasiswa (Simner, et al., 2000: 43).

Berbagai program pengembangan telah menggunakan nilai TOEFL atau TOEFLLike untuk tujuan-tujuan sebagaimana diuraikan di atas misalnya untuk studi ke luar negeri, lulus suatu program pembelajaran, mendapatkan hibah, naik pangkat, dan sebagainya. Dalam program-program ini, nilai TOEFL atau TOEFL-Like dianggap sebagai kriteria yang cukup kuat untuk memprediksi keberhasilan; mereka yang bernilai tinggi diprediksi akan berhasil dalam mengikuti program yang dita- warkan. Praktik-praktik ini telah terjadi di tingkat interna-sional, nasional, maupun lokal. Walaupun sudah mengikuti kemajuan teknologi komunikasi dan informasi, TOEFL masih dipandang sebagai program tes profisiensi yang populer karena format tes yang cenderung sederhana dan pelaksanaan tes yang baku.

Untuk tujuan penerimaan mahasiswa baru, tidak kurang dari 20 Program Doktor terkemuka di Amerika Serikat mensyaratkan nilai TOEFL 571 sedangkan beberapa program Pasca Sarjana terkemuka di Australia mensyaratkan nilai TOEFL 580 (Roemer, 2002: 7). Perkembangan terkini menunjukkan bahwa beberapa universitas di Amerika Serikat telah menaikkan persyaratan nilai TOEFL dari 550 ke 600 (Roemer, 2002: 40).

Di kawasan Asia, lulusan sekolah menengah di India, misalnya, harus memiliki kesiapan yang baik untuk dapat meneruskan studinya di luar negeri dengan menguasai beberapa tes antara lain SAT, GRE, GMAT, dan TOEFL. Di dunia bisnis di Filipina, test profisiensi bahasa Inggris sangat ditekankan, termasuk TOEFL. Nilai TOEFL yang tinggi dapat meningkatkan kualitas sumber daya manusia setempat. Hasil survei menunjukkan hasil yang banyak, beberapa sebagai berikut: $77 \%$ orang dewasa Filipina mengerti spoken English, $76 \%$ membaca buku-buku bahasa Inggris, $61 \%$ menulis dalam bahasa Inggris, 54\% berbicara bahasa Inggris, dan 7\% tidak bisa berbahasa Inggris (Alave, 2006).

Di Indonesia, penguasaan bahasa Inggris yang rendah telah menghalangi mahasiswa dari luar Jawa (misalnya, Maluku) untuk memperoleh beasiswa dari Negeri Belanda sejak tahun 2000 me-lalui program STUDNED. Program beasiswa ini mensyaratkan nilai TOEFL 550 bagi para pelamarnya (Antara, Jakarta, December 5, 2008). Lulusan Universitas Semarang disyaratkan memiliki nilai TOEFL 400 (Antara, Jakarta, March 5, 2004), sedangkan Universitas Diponegoro (UNDIP) mensyaratkan nilai TOEFL 
400 untuk penerimaan mahasiswa baru (Antara, Jakarta, Oktober 2003).

\section{METODE}

Dengan menggunakan cara survei, penelitian melibatkan sejumlah 24.909 mahasiswa baru UNY tahun akademik 2005/2006 hingga tahun akademik 2009/2010 yang terdiri atas 4.731 mahasiswa FIP, 4.574 mahasiswa FBS, 4.158 mahasiswa FISE, 4.724 mahasiswa FMIPA, 4.045 mahasiswa FT, dan 2.677 mahasiswa FIK. Penelitian menggunakan formatformat isian sebagai instrumen penelitian. Format utama adalah daftar lajur dan baris untuk memasukkan data-data mengenai nama mahasiswa, nomor mahasiswa, program studi, fakultas, tahun akademik TOEFL, listening, structure, reading, dan TOEFL. Format pendukung berupa daftar isian untuk merangkum nilai-nilai TOEFL fakultas, program studi, dan tahun akademik.

Data penelitian berupa nilai tes TOEFL-Like yang terdiri dari tiga mata tes: Listening, Reading, dan Structure \& Written Expression. Data dikumpulkan dengan cara mendata nilai test TOEFL-Like mahasiswa baru di P3B UNY. Data dibedakan menjadi tiga kelompok besar: menurut lembaga, menurut tahun akademik, dan menurut komponen tes. Menurut lembaga, data dibedakan menjadi kelompok universitas, kelompok fakultas, dan kelompok program studi. Menurut tahun akademik, data dibedakan menjadi lima kelompok sesuai dengan tahun akademik 2005 sampai 2009. Menurut komponen tes, data dikelompokkan menurut Listening, Reading, dan Structure \& Written Expression.

Data penelitian dianalisis secara kuantitatif dengan menggunakan Nilai Kasar, Rerata, Deviasi Standar, Frekuensi, dan prosentase sebagai alat statistik (Johnson, \& Christensen, 2008: 105). Nilai Kasar digunakan untuk membuat peringkat per mahasiswa. Rerata, Deviasi Standar, dan Frekuensi digunakan untuk membuat nilai TOEFL dan peringkat tingkat universitas dan fakultas. Statistik rerata digunakan untuk nilai TOEFL dan peringkat Program Studi. Prosentase digunakan untuk mengkonversi nilai kasar Listening, Structure, dan Reading.

\section{TEMUAN DAN PEMBAHASAN Peta Penguasaan Bahasa Inggris Maha- siswa Baru UNY}

Tabel 1 menunjukkan skor yang mewakili penguasaan bahasa Inggris mahasiswa baru UNY. Uraian hasil analisis data yang lebih terinci disajikan selanjutnya secara berturut-turut mengikuti Tabel 1 .

Untuk mendapatkan gambaran umum, penguasaan bahasa Inggris mahasiswa baru UNY tahun 2005-2009 ditunjukkan dengan nilai rerata sebesar 367 dan deviasi standar sebesar 50,65. Secara umum, rerata 367 ini tidak termasuk tinggi. Yang telah banyak dilakukan oleh lembagalembaga pelatihan atau kursus bahasa Inggris, angka 367 biasanya dimasukkan ke dalam tingkat intermediate atau menengah. Untuk pembandingan, Departeman Pendidikan Nasional, Direktorat Jenderal Manajemen Pendidikan Dasar dan Menengah (2009) mengadakan uji coba TOEFL-Like di SMA-SMA terpilih seluruh Indonesia dan mendapatkan angka 418 sebagai nilai rerata.

Dalam hitungan frekuensi, dari 24.909 mahasiswa, nilai tertinggi, 583, dicapai oleh satu orang mahasiswa dan nilai tertinggi kedua, 560, dicapai oleh satu orang mahasiswa. Nilai yang paling tinggi kedua (Frekuensi $=5,7 \%$ ) adalah 400 , yang dicapai oleh 1.416 orang mahasiswa. Nilai 400 menunjukkan penguasaan bahasa preadvanced. Walaupun frekuensinya berbesaran $5,7 \%$, dapat dikatakan bahwa sejumlah kecil mahasiswa baru UNY sudah memiliki penguasaan bahasa pada tingkat yang cukup tinggi. Ini merupakan modal yang menjanjikan dalam hal kualitas mahasiswa dari segi penguasaan bahasa Inggris. Kemudian berturut-turut, nilainilai yang utuh adalah sebagai berikut. 
Tabel 1. Penguasaan Bahasa Inggris Mahasiswa Baru UNY Tahun 2005-2009 dari Rerata dan Standar Deviasi tingkat Universitas

\begin{tabular}{lcrrrr}
\hline Mata Uji & $\begin{array}{c}\text { Jumlah } \\
\text { Subjek }\end{array}$ & $\begin{array}{c}\text { Nilai } \\
\text { Terendah }\end{array}$ & $\begin{array}{c}\text { Nilai } \\
\text { Tertinggi }\end{array}$ & Rerata & \multicolumn{1}{c}{$\begin{array}{c}\text { Deviasi } \\
\text { Standar }\end{array}$} \\
\hline Listening & 24907 & 00,00 & 49,00 & 13,6061 & 4,21362 \\
Structure & 24909 & 00,00 & 36,00 & 12,5023 & 4,02299 \\
Reading & 24909 & 1,00 & 49,00 & 17,7503 & 5,28835 \\
TOEFL & 24909 & 25,00 & 583,00 & 367,2180 & 50,65146 \\
\hline
\end{tabular}

Sejumlah 0,2\% mahasiswa memiliki nilai 500 atau lebih (advanced). Sejumlah 39,6\% mahasiswa memiliki nilai 375 atau lebih (intermediate atau lebih). Dan sejumlah $68,7 \%$ mahasiswa memiliki nilai 350 atau lebih (pre-intermediate atau lebih). Apabila nilai TOEFL dikaitkan dengan seleksi mahasiswa baru, maka UNY akan mendapatkan lebih kurang 40\% persen dari jumlah pendaftar dengan nilai TOEFL 375 atau lebih dan lebih kurang 70\% dari jumlah pendaftar dengan nilai TOEFL 350.

Dari segi sebaran nilai, distribusi skor TOEFL mahasiswa baru UNY tahun 2005-2009 ditandai dengan angka deviasi standar sebesar 50,6514. Ini adalah besaran deviasi standar yang rendah mengingat bahwa deviasi standar TOEFL adalah 100. Ini menunjukkan bahwa, pada umumnya, penguasaan bahasa Inggris mahasiswa baru UNY cukup homogen. Hal ini dapat dipahami karena para mahasiswa berasal dari tingkatan sekolah yang sama dan membawa hasil belajar yang tidak sangat berbeda antara satu sekolah dengan sekolah lain.

Dilihat dari komponen bahasa, nilai tertinggi terdapat pada Reading (35,5\%), menyusul Structure $(31,25 \%)$, dan kemudian Listening $(27,2 \%)$. Fenomena ini dapat dipahami dengan baik mengingat bahwa pembelajaran bahasa Inggris di sekolah menengah banyak menekankan kegiatan dan keterampilan membaca. Rendahnya persentase untuk Listening mengisyaratkan bahwa, dalam pengalaman pembelajarannya, mahasiswa baru tidak mendapatkan latihan menyimak dengan kualitas dan kuantitas yang cukup. Untuk penguasaan Structure, dapat dikatakan bahwa mahasiswa baru kurang memiliki pengetahuan dan keterampilan yang cukup karena, sebenarnya, Structure adalah komponen bahasa yang paling tersedia dan paling mudah dipelajarai dan dikuasai. Selain itu, pembelajaran Structure cenderung memiliki aturan yang lebih baku dari pada Reading atau Listening. Namun demikian, persentase sebesar 31,25 dapat dikatakan terlalu rendah untuk pembelajar lulusan sekolah menengah tingkat atas.

\section{Nilai TOEFL Mahasiswa Baru tingkat Fakultas}

Tabel 2 menunjukkan skor TOEFL mahasiswa baru pada tingkat fakultas. Untuk memudahkan pembahasan, hasil analisis rerata fakultas disusun secara ranking dari angka tertinggi ke bawah. Komponen tes dan statistik yang digunakan sama dengan yang ada pada Tabel 1 .

Dari Tabel 2, diketahui bahwa rerata tertinggi terdapat pada FMIPA sebesar 378,81 . Ranking kedua adalah FISE $(372,83)$ dengan selisih rerata 5 angka di bawah ranking pertama FMIPA. Ranking ketiga diduduki FT dengan rerata 367,18, juga selisih lima angka dari ranking di atasnya FISE. Raking keempat dan kelima didapat oleh FBS dan FIP, masingmasing dengan rerata 363,83 dan 363,77. FIK menduduki ranking terakhir dengan rerata 356,44 .

Dilihat dari statistik deviasi standar, diketahui bahwa FIK memiliki angka deviasi standar yang paling kecil $(28,10)$. Ini menunjukkan bahwa mahasiswa baru FIK relatif lebih homogen dalam hal profisiensi bahasa Inggris dari pada fakultas-fakultas 
Tabel 2. Penguasaan Bahasa Inggris Mahasiswa Baru UNY Tahun 2005-2009 dari Rerata dan Standar Deviasi tingkat Fakultas

\begin{tabular}{llcccccccc}
\hline \multirow{2}{*}{ No } & \multirow{2}{*}{ Fakultas } & \multicolumn{2}{c}{ Listening } & \multicolumn{2}{c}{ Structure } & \multicolumn{2}{c}{ Reading } & \multicolumn{2}{c}{ TOEFL } \\
\cline { 3 - 9 } & & Rerata & SD & Rerata & SD & Rerata & SD & Rerata & SD \\
\hline 1 & FMIPA & 13,53 & 4,03 & 13,08 & 4,09 & 19,25 & 5,43 & 378,81 & 36,31 \\
2 & FISE & 13,67 & 4,15 & 12,43 & 3,87 & 17,82 & 5,07 & 372,83 & 35,61 \\
3 & FT & 13,77 & 4,27 & 12,20 & 3,83 & 17,38 & 4,98 & 367,18 & 42,24 \\
4 & FBS & 14,41 & 5,05 & 13,38 & 4,64 & 18,55 & 5,98 & 363,83 & 85,23 \\
5 & FIP & 13,20 & 3,64 & 12,00 & 3,75 & 17,23 & 4,88 & 363,77 & 43,30 \\
6 & FIK & 12,66 & 3,49 & 11,57 & 3,33 & 15,40 & 4,11 & 356,44 & 28,10 \\
\hline
\end{tabular}

Tabel 3 Penguasaan Bahasa Inggris Mahasiswa Baru UNY Tahun 2005-2009 menurut Tahun Akademik tingkat Universitas

\begin{tabular}{lcccccccccc}
\hline \multirow{2}{*}{ No } & Tahun & \multirow{2}{*}{ N } & \multicolumn{2}{c}{ Listening } & \multicolumn{2}{c}{ Structure } & \multicolumn{2}{c}{ Reading } & \multicolumn{2}{c}{ TOEFL } \\
\cline { 4 - 10 } & & & Rerata & SD & Rerata & SD & Rerata & SD & Rerata & SD \\
\hline 1 & $2009-2010$ & 4567 & 13,67 & 4,50 & 13,13 & 4,09 & 18,60 & 5,70 & 376,19 & 38,36 \\
2 & $2008-2009$ & 4186 & 13,51 & 4,58 & 12,56 & 4,17 & 18,67 & 5,88 & 373,37 & 39,18 \\
3 & $2005-2006$ & 4979 & 13,84 & 3,95 & 12,87 & 3,88 & 17,53 & 4,95 & 372,95 & 34,73 \\
4 & $2007-2008$ & 6089 & 13,70 & 4,22 & 12,23 & 3,98 & 16,32 & 4,72 & 360,66 & 52,98 \\
5 & $2006-2007$ & 5088 & 13,26 & 3,81 & 11,83 & 3,87 & 18,14 & 4,94 & 356,32 & 71,63 \\
\hline
\end{tabular}

lain. Sebaliknya, FBS memilik angka deviasi standar paling tinggi $(85,23)$, jauh di atas fakultas-fakultas lain. Ini menunjukkan bahwa FBS memiliki mahasiswa baru dengan profisiensi bahasa Inggris yang sangat heterogen, ada yang sangat tinggi, tetapi juga ada yang sangat rendah. Fakultas-fakultas lain menunjukkan nilai deviasi standar yang bergerak antara 35 sampai 43, dan berada di antara dua kutub tinggi (FBS) dan rendah (FIK). Dengan demikian keempat fakultas ini (FIP, FISE, FMIPA, dan FT) memiliki mahasiswa baru dengan profisiensi bahasa Inggris dengan tingkat homoginitas yang relatif berimbang.

Dalam hal penguasaan komponen bahasa, perolehan nilai di tingkat fakultas menunjukkan kemiripan dengan perolehan nilai di tingkat universitas. Nilai tertinggi terdapat pada Reading diikuti, berturut-turut, oleh Structure dan Listening pada masing-masing fakultas. Beberapa fakta menonjol dapat disebutkan sebagai berikut. Mahasiswa baru FMIPA menunjukkan nilai rerata tertinggi untuk Reading $(38,5 \%)$, tiga angka persentase di atas ratarata universitas. Sebaliknya, mahasiswa baru FIK mencatatkan nilai terendah dalam Reading (30,8\%), hampir 5 angka di bawah rata-rata universitas. Mahasiswa baru FBS mendapatkan nilai tertinggi untuk Listening (36,02\%), lebih dari 6 angka di atas rata-rata universitas.

\section{Nilai per Tahun Akademik tingkat Uni- versitas}

Untuk mengetahui sebaran nilai dari tahun ke tahun, dilakukan juga analisis deskriptif dengan Tahun Akademik sebagai kriteria. Hasil analisis rerata dan deviasi standar dapat dilihat dalam Tabel 3.

Hal-hal yang dapat dilihat dari hasil analisis ini adalah sebagai berikut. Rerata tertinggi dicapai oleh mahasiswa baru Tahun Akademik 2009-2010 $(376,19)$ dan rerata terendah dicapai oleh mahasiswa baru Tahun Akademik 2006-2007 (356,32). Kemudian, berturut-turut, pencapaian nilai adalah Tahun Akademik 2008-2009 $(373,37)$, Tahun Akademik 2005-2006 (372,95), dan Tahun Akademik 2007-2008 $(360,66)$. Dengan perkecualian Tahun Akademik 2006-2007, tampaknya tidak ada perbedaan mencolok yang terdapat dalam nilai rerata dari tahun ke tahun. Dalam hal sebaran nilai, Tahun Akademik 
Tabel 4 Penguasaan Bahasa Inggris Mahasiswa Baru UNY Tahun 2005-2009 menurut Tahun Akademik tingkat Fakultas

\begin{tabular}{llccccc}
\hline No & Fakultas & \multicolumn{5}{c}{ Tahun } \\
\cline { 3 - 6 } & & $2005-2006$ & $2006-2007$ & $2007-2008$ & $2008-2009$ & $2009-2010$ \\
\hline 1 & FIP & 372,55 & 367,26 & 346,53 & 363,00 & 378,04 \\
2 & FBS & 380,13 & 309,82 & 364,66 & 383,48 & 383,91 \\
3 & FISE & 381,49 & 377,12 & 372,45 & 378,27 & 383,14 \\
4 & FMIPA & 371,20 & 370,11 & 368,97 & 373,79 & 372,63 \\
5 & FT & 369,52 & 360,96 & 356,55 & 376,55 & 373,31 \\
6 & FIK & 356,64 & 356,25 & 353,15 & 358,16 & 359,77 \\
\hline
\end{tabular}

2006-2007 juga memiliki penyimpangan dengan angka deviasi standar yang sangat tinggi $(71,63)$. Sementara itu, tahun-tahun yang lain memiliki deviasi standar antara 34 sampai 53.

Pemerolehan nilai TOEFL dari tahun ke tahun sebagaimana terurai di atas cukup fluktuatif. Walaupun ada kecenderungan untuk mengarah naik, fluktuasi dari tahun ke tahun sukar untuk dapat diprediksi. Dilihat dari nilai deviasi standar, misalnya, tiap tahun akademik menunjukkan perbedaan. Mahasiswa baru Tahun Akademik 2005-2006 terlihat paling homogen sedangkan mahasiswa baru Tahun Akademik 2006-2007 terlihat paling heterogen. Dalam hal pemerolehan nilai untuk masing-masing komponen bahasa, mahasiswa baru UNY menunjukkan keajegan yang cukup tinggi dalam Listening (berkisar pada 33,75\%). Pemerolehan nilai untuk Structure menunjukkan tendensi sama dengan pemerolehan TOEFL secara keseluruhan. Pemerolehan nilai untuk komponen ini cukup fluktuatif dari tahun ke tahun dengan modus berkisar 31,25\%. Reading mengikuti kecenderungan yang sama dengan Structure. Dengan fluktuasi yang cukup tinggi pula, modus nilai Reading berkisar pada besaran $36,8 \%$.

\section{Nilai per Tahun Akademik tingkat Fakultas}

Dengan penghitungan statistik yang sama, pemerolehan nilai dari tahun ke tahun untuk fakultas memiliki kecenderungan berbeda dari pada pemerolehan nilai tingkat universitas. Hasil analisis rerata disajikan dalam Tabel 4.
Dua fakultas, MIPA dan FIK, menunjukkan pemerolehan nilai yang cukup stabil dari tahun ke tahun. Kecenderungan kesamaan rerata untuk MIPA berkisar pada angka 371 se-dangkan untuk FIK pada angka 356. Keempat fakultas yang lain menunjukkan kecenderungan yang cukup fluktuatif. FBS dan FIP menunjukkan perbedaan perolehan nilai yang $\mathrm{cu}-$ kup besar, FBS dengan rentangan antara 309 sampai 383 dan FIP dengan rentangan nilai antara 346 sampai 378 . Tingkat fluktuasi sedang terdapat pada FISE dan FT; FISE dengan rentangan antara 372 sampai 383 dan FT dengan rentangan nilai antara 356 sampai 376. Fakta ini dan yang baru saja disebutkan di atas memperkuat temuan bahwa nilai TOEFL mahasiswa baru memiliki fluktuasi yang cukup tinggi dari tahun ke tahun dan tidak mudah untuk diprediksi.

\section{Nilai Rerata TOEFL Program Studi}

Penyajian nilai TOEFL mahasiswa baru tingkat program studi mengikuti cara yang sama dengan tingkat universitas dan fakultas. Untuk menyederhanakan penyajian, hanya nilai rerata yang disajikan untuk tingkat program studi. Ini mengingat bahwa statistik ini adalah yang paling banyak berguna dan digunakan oleh program studi. Untuk tujuan yang sama pula, nilai prodi disajikan dalam bentuk ranking TOEFL, dari nilai tertinggi sampai dengan nilai terendah. Hasil penghitungan rerata disajikan dalam Tabel 5.

Tiga Prodi memiliki rerata TOEFL 400 atau lebih (Pre-advanced): Sastra Inggris, 
Tabel 5 Penguasaan Bahasa Inggris Mahasiswa Baru UNY Tahun 2005-2009 tingkat Prodi dari Listening, Structure, Reading, dan TOEFL

\begin{tabular}{|c|c|c|c|c|c|}
\hline No & Prodi & Listening & Structure & Reading & TOEFL \\
\hline 1 & Sastra Inggris & 18,48 & 16,40 & 23,79 & 417,36 \\
\hline 2 & Dik Inggris & 17,24 & 16,38 & 21,79 & 409,37 \\
\hline 3 & Akta Mengajar (FIP) & 16,00 & 16,00 & 19,00 & 400,00 \\
\hline 4 & Informatika & 15,75 & 14,97 & 20,11 & 395,33 \\
\hline 5 & Dik Matematika & 14,40 & 13,92 & 21,42 & 391,31 \\
\hline 6 & Dik IPS & 14,46 & 13,30 & 19,43 & 384,13 \\
\hline 7 & Dik Akuntansi & 14,01 & 13,40 & 20,17 & 383,76 \\
\hline 8 & Adm Negara & 14,80 & 13,28 & 18,94 & 382,50 \\
\hline 9 & Manajemen & 14,86 & 13,33 & 19,19 & 382,38 \\
\hline 10 & Dik Kimia & 13,59 & 13,43 & 19,75 & 381,54 \\
\hline 11 & Akuntansi S1 & 14,10 & 13,83 & 18,84 & 381,12 \\
\hline 12 & Kimia & 13,81 & 13,63 & 18,71 & 379,39 \\
\hline 13 & Dik Jerman & 14,11 & 13,44 & 18,69 & 379,09 \\
\hline 14 & Dik Fisika & 13,26 & 13,15 & 19,74 & 379,08 \\
\hline 15 & Matematika & 13,32 & 13,57 & 18,95 & 378,53 \\
\hline 16 & Sipil dan Perencanaan & 14,68 & 13,03 & 18,32 & 378,33 \\
\hline 17 & Dik Teknik Elektro & 14,50 & 12,27 & 19,13 & 377,91 \\
\hline 18 & Dik Biologi & 13,71 & 12,85 & 19,14 & 377,62 \\
\hline 19 & Dik Geografi & 14,16 & 12,44 & 18,09 & 374,26 \\
\hline 20 & PAUD & 13,75 & 12,85 & 17,78 & 374,17 \\
\hline 21 & Dik Ekop & 13,38 & 12,41 & 18,19 & 372,19 \\
\hline 22 & Dik Indonesia & 13,79 & 12,34 & 17,95 & 372,12 \\
\hline 23 & Dik IPA & 13,61 & 12,36 & 18,13 & 371,77 \\
\hline 24 & PGSD D2 & 13,17 & 11,99 & 18,81 & 371,61 \\
\hline 25 & Dik Teknik Bangunan & 13,14 & 12,34 & 18,72 & 371,58 \\
\hline 26 & Dik Elektronika & 13,45 & 12,34 & 18,46 & 370,39 \\
\hline 27 & Dik Boga & 12,87 & 12,49 & 18,02 & 369,89 \\
\hline 28 & Dik Teknik Mesin & 13,79 & 11,90 & 17,75 & 369,14 \\
\hline 29 & Bimbingan dan Konseling & 13,45 & 12,07 & 17,74 & 368,71 \\
\hline 30 & Dik Luar Biasa & 13,47 & 11,56 & 18,15 & 368,27 \\
\hline 31 & Adm Pendidikan & 13,67 & 11,84 & 17,58 & 368,01 \\
\hline 32 & Teknologi Pendidikan & 13,13 & 12,17 & 17,64 & 367,70 \\
\hline 33 & Biologi & 12,90 & 12,03 & 17,96 & 367,15 \\
\hline 34 & TS dan Bangunan D3 & 14,52 & 11,89 & 16,30 & 366,94 \\
\hline 35 & Dik Sejarah & 13,74 & 11,71 & 16,73 & 365,55 \\
\hline 36 & Teknik Otomotif D3 & 13,82 & 12,01 & 16,48 & 365,48 \\
\hline 37 & Fisika & 12,56 & 12,07 & 17,70 & 365,35 \\
\hline 38 & Teknik Elektronika D3 & 13,16 & 11,43 & 17,76 & 365,28 \\
\hline 39 & Busana S1 & 13,16 & 12,50 & 17,00 & 365,00 \\
\hline 40 & Dik Busana & 12,97 & 12,59 & 16,28 & 364,86 \\
\hline 41 & Dik Teknik Otomotif & 13,20 & 11,60 & 17,07 & 363,68 \\
\hline 42 & Teknik Elektro D3 & 13,63 & 11,53 & 16,64 & 363,66 \\
\hline 43 & PGSD S1 & 12,85 & 12,34 & 16,41 & 362,82 \\
\hline 44 & Dik PKN & 13,09 & 11,38 & 17,11 & 362,55 \\
\hline 45 & Dik Sosiologi & 13,02 & 11,80 & 16,42 & 361,87 \\
\hline 46 & Akuntansi D3 & 12,94 & 11,85 & 16,29 & 361,82 \\
\hline 47 & Dik Musik & 12,57 & 12,19 & 16,40 & 361,64 \\
\hline 48 & Sastra Indonesia & 12,75 & 11,56 & 16,88 & 361,19 \\
\hline 49 & Busana D3 & 13,42 & 11,70 & 15,79 & 360,75 \\
\hline 50 & Dik Adm Kantor & 12,68 & 11,43 & 16,94 & 360,59 \\
\hline 51 & Teknik Mesin D3 & 13,01 & 11,17 & 16,63 & 360,07 \\
\hline
\end{tabular}




\begin{tabular}{|c|c|c|c|c|c|}
\hline 52 & Manajemen Pasar D3 & 13,40 & 11,59 & 15,43 & 359,94 \\
\hline 53 & Dik Kepelatihan & 12,97 & 11,62 & 15,87 & 359,81 \\
\hline 54 & Dik Luar Sekolah & 12,30 & 11,72 & 16,66 & 359,50 \\
\hline 55 & Ilmu Sejarah & 13,23 & 11,43 & 15,86 & 359,32 \\
\hline 56 & PGSD KS & 13,20 & 11,50 & 15,96 & 359,27 \\
\hline 57 & Dik JKR & 12,75 & 11,56 & 15,81 & 358,16 \\
\hline 58 & Ilmu Keolahragaan & 12,69 & 11,59 & 15,66 & 357,09 \\
\hline 59 & Dik Tari & 12,55 & 11,63 & 15,81 & 357,04 \\
\hline 60 & PGSD Penjas S1 & 12,55 & 11,80 & 15,23 & 356,31 \\
\hline 61 & Boga D3 & 12,92 & 11,25 & 15,59 & 356,07 \\
\hline 62 & PGSD Penjas D2 & 12,45 & 11,27 & 14,60 & 351,72 \\
\hline 63 & Sekretaris D3 & 12,09 & 11,61 & 14,75 & 350,60 \\
\hline 64 & PGTK & 12,30 & 10,71 & 15,37 & 349,66 \\
\hline 65 & Mekatronika & 14,32 & 12,39 & 17,22 & 345,77 \\
\hline 66 & Dik Kerajinan & 11,86 & 10,36 & 14,81 & 345,65 \\
\hline 67 & Tata Rias & 12,69 & 11,40 & 14,60 & 334,27 \\
\hline 68 & Dik Perancis & 14,55 & 13,44 & 18,34 & 330,50 \\
\hline 69 & Dik Seni Rupa & 12,51 & 11,59 & 16,10 & 325,54 \\
\hline 70 & Dik Jawa & 13,12 & 12,21 & 17,00 & 307,40 \\
\hline 71 & Analisis Kebijakan Pend & 13,05 & 11,51 & 15,30 & 277,48 \\
\hline
\end{tabular}

Pendidikan Bahasa Inggris, dan Akta Mengajar. Untuk Program Akta Mengajar, hanya ada satu mahasiswa yang mengikuti TOEFL MABA selama kurun waktu lima tahun. Untuk selanjutnya, program ini tidak dimasukkan ke dalam pembahasan. Kategori Intermediate (TOEFL 375 atau lebih) diduduki oleh 15 Prodi: Informatika, Pendidikan Matematika, Pendidikan IPS, Pendidikan Akuntansi, Administrasi Negara, Manajemen, Pendidikan Kimia, Akuntansi S1, Kimia, Pendidikan Bahasa Jerman, Pendidikan Fisika, Matematika, Sipil dan Perencanaan, Pendidikan Teknik Elektro, dan Pendidikan Biologi. Apabila TOEFL 350 (Pre-intermediate) dijadikan batas terendah untuk mahasiswa baru UNY, delapan Prodi masih berada di bawah garis ini: PGTK, Mekatronika, Pendidikan Kerajinan, Tata Rias, Pendidikan Bahasa Perancis, Pendidikan Seni Rupa, Pendidikan Bahasa Jawa, dan Analisis Kebijakan Pendidikan. Sisanya, sejumlah 45 Prodi berada dalam kategori Pre-intermediate.

\section{Fluktuasi Nilai dari Tahun ke Tahun}

Prodi Sastra Inggris dan Pendidikan Bahasa Inggris cukup ajeg menduduki ranking 1 dan 2 sepanjang lima tahun, saling berkejaran antara kisaran nilai rerata 390 sampai 434. Prodi Pendidikan Akuntansi juga menunjukkan keajegan yang cukup dengan pencapaian nilai rerata 386 (2005), 385 (2006), 374 (2007), 384 (2008) dan 387 (2009). Prodi Teknik Informatika, yang mengikuti TOEFL MABA sejak tahun 2007, juga menujukkan konsistensi yang cukup (385, 401, dan 397). Prodi-prodi lain menunjukkan pencapaian rerata nilai yang sangat fluktuatif. Prodi Pendidikan Teknik Elektro, misalnya, menduduki ranking 2 tahun 2005 (394) dan 3 tahun 2006 (392), tetapi turun ke ranking 16 tahun 2007 (369) dan ranking 37 tahun 2008 (369), dan naik sedikit ke ranking 27 tahun 2009 (377). Fluktuasi yang sangat besar ditunjukkan oleh Prodi Pendidikan Bahasa Perancis, misalnya $(393,334,367,377$, dan 391), atau Prodi Pendidikan Bahasa Jawa (392, 323, 359, 374, dan 365).

Ada satu kecenderungan bahwa makin tinggi nilai TOEFL, maka makin konsisten pula pencapaian nilai dari waktu ke waktu. Hal ini berhubungan dengan konsistensi penguasaan bahasa Inggris seseorang. Kecenderungan lain dalam hal konsistensi ini adalah bahwa makin tinggi nilai TOEFL seseorang, makin sukar baginya untuk meningkatkan nilainya 
Tabel 6 Pemerolehan Nilai Listening, Structure, Reading dari Skor dan Persentase

\begin{tabular}{llllllll}
\hline \multirow{2}{*}{ No } & \multirow{2}{*}{ Tingkat } & \multicolumn{2}{c}{ Listening } & \multicolumn{2}{c}{ Structure } & \multicolumn{2}{c}{ Reading } \\
\cline { 3 - 7 } & & Sekor & $\%$ & Sekor & $\%$ & Sekor & $\%$ \\
\hline 0 & Universitas & 13,60 & 27,2 & 12,50 & 31,25 & 17,75 & 35,5 \\
1 & FIP & 13,27 & 26,54 & 12,09 & 30,22 & 17,49 & 34,98 \\
2 & FBS & 14,41 & 28,82 & 13,36 & 33,4 & 18,55 & 37,1 \\
3 & MIPA & 13,56 & 27,12 & 13,13 & 32,82 & 19,39 & 38,78 \\
4 & FISE & 13,67 & 27,34 & 12,44 & 31,1 & 17,83 & 35,66 \\
5 & FT & 13,77 & 27,54 & 12,20 & 30,5 & 17,36 & 34,72 \\
6 & FIK & 12,66 & 25,32 & 11,59 & 28,97 & 15,44 & 30,88 \\
\hline
\end{tabular}

dibanding dengan mereka yang masih rendah nilai TOEFLnya.

\section{Gambaran Tiga Komponen Tes: Listen- ing, Structure, Reading}

Untuk memudahkan cara melihat penguasaan mahasiswa terhadap tiga komponen test, dilakukan persentase pada nilai rerata. Penghitungan persentase didasarkan pada jumlah soal untuk Listening (50), Structure (40), dan Reading (50). Hasil konversi nilai rerata ke persentase dapat dilihat dalam Tabel 6 .

Kecenderungan umum menunjukkan bahwa penguasaan bahasa Inggris mahasiswa berturut-turut dari tinggi ke rendah adalah Reading $(35,5)$ Structure $(31,25)$ dan Listening $(27,2)$ dengan selisih angka 4 sampai 5 butir. Kecenderungan ini terjadi baik di tingkat universitas maupun di masing masing fakultas. Tingginya penguasaan membaca mahasiswa dapat dipahami dari kenyataan bahwa di sekolah-sekolah sebelumnya, mahasiswa telah banyak mendapat pajanan dan latihan dalam membaca. Fenomena ini dikuatkan dengan makin banyaknya media cetak dan elektronik yang dapat diakses oleh mahasiswa dalam berbagai keperluan atau tujuan. Sebaliknya, rendahnya keterampilan menyimak menunjukkan bahwa mahasiswa tidak mendapat pajanan dan latihan yang cukup dalam keterampilan ini. Media audio yang tersedia, baik di lingkungan sekolah maupun di luar, belum dapat membantu mahasiswa untuk mencapai keterampilan menyimak yang tinggi. Sementara itu, kecenderungan umum untuk penguasaan tata bahasa mengisyaratkan bahwa pengajaran tata bahasa di sekolah cukup rata dan baku sehingga tidak menghasilkan isyarat-isyarat yang mencolok.

Untuk Listening, dengan persentasi tertinggi $28,82 \%$ (FBS) dan terendah 25,32 (FIK), nilai untuk Listening menunjukkan homogenitas yang cukup tinggi. Ini berarti bahwa mahasiswa baru UNY memiliki penguasaan listening yang cukup imbang dengan rerata $27,12 \%$, persentase terendah di antara tiga komponen test. Keadaan ini dapat disebabkan oleh dua hal. Pertama, pembelajaran Listening di tingkat sekolah menengah atas belum menghasilkan keterampilan menyimak yang memadai. Walaupun kurikulum sekolah tidak pernah menentukan perbedaan di antara keempat keterampilan berbahasa, kenyataan menunjukkan bahwa pembelajaran Listening masih kurang mendapatkan perhatian yang cukup. Kedua, mahasiswa baru UNY nampaknya tidak cukup mendapat pajanan bahasa Inggris lisan di dalam maupun di luar sekolah. Walaupun telah banyak terdapat media audio yang dapat diakses baik di dalam maupun di luar sekolah, seperti radio/TV dan Internet, nampaknya ketersediaan media ini belum berdampak positif untuk pembelajaran bahasa Inggris di sekolah.

Untuk Structure, perbedaan nilai menunjukkan tingkat yang tidak terlalu tinggi tetapi juga tidak terlalu rendah. Persentase nilai tertinggi terlihat pada FBS $(33,4)$ dan terendah pada FIK $(28,97)$. 
Dengan nilai rerata 31,25, mahasiswa baru UNY memperlihatkan penguasaan tata bahasa Inggris yang tidak terlalu tinggi, walaupun pembelajaran tata bahasa dalam kelas dapat dikatakan cukup dalam jumlah maupun cakupan. Hampir semua jenis kurikulum yang digunakan di sekolah selalu memasukkan butir-butir tata bahasa yang lengkap yang disebar dari semester 1 (kelas 10) sampai semester 6 (kelas 12). Kesenjangan ini nampaknya mudah dipahami karena pengelolaan bahan tata bahasa di kelas tentu saja tidak diorientasikan ke Structure dalam TOEFL. Khusus untuk komponen Structure, dapat dipastikan diperlukan pembelajaran tambahan, baik di dalam maupun di luar kelas, dengan bahan pembelajaran yang dikhususkan untuk TOEFL.

Untuk Reading, nilai menunjukkan perbedaan yang cukup tinggi antarfakultas. Nilai tertinggi tercatat pada FMIPA $(38,78)$ dan nilai terendah pada FIK $(30,88)$. Mahasiswa baru FBS menunjukkan keterampilan membaca yang cukup tinggi, hanya selisih sekitar 1,7 dari mahasiswa baru MIPA. Ketiga fakultas lainnya (FIP, FISE, dan FT) memiliki nilai rerata yang mendekati kecenderungan Universitas, yakni berentang dari 34,72 sampai 35,66. Dengan rerata sekitar 35,5, mahasiswa baru UNY dapat dikatakan memiliki keterampilan membaca yang cukup. Keterampilan membaca ini dapat digunakan sebagai modal yang kuat untuk usaha-usaha peningkatan melalui pelatihan-pelatihan. Peningkatan keterampilan membaca melibatkan komponen kosa kata yang cukup besar dan membutuhkan waktu yang lebih panjang daripada peningkatan keterampilan bahasa yang lain.

\section{Kemungkinan-kemungkinan Program Akademik}

Beberapa hal dapat disampaikan mengenai kemungkinan-kemungkinan yang dapat dilakukan sehubungan dengan hasil TOEFL mahasiswa baru UNY.
Pertama, TOEFL untuk mahasiswa baru masih perlu dilakukan dari tahun ke tahun. Ini mengingat bahwa karakteristik mahasiswa cenderung berbeda dari tahun ke tahun, terutama lintas program studi. Sebagaimana telah disebutkan di atas, memang ada kemungkinan bahwa semakin tinggi nilai yang dicapai oleh mahasiswa, maka semakin tinggilah keajegan dalam pemerolehan nilai. Namun demikian, tetap saja terlihat jelas bahwa dari tahun ke tahun mahasiswa menunjukkan pemerolehan TOEFL yang berbeda, terutama untuk tingkat program studi. Apabila manajemen prodi memiliki data nilai TOEFL mahasiswa baru tiap tahun, perencanaan-perencanaan yang lebih matang dapat dilakukan yang berhubungan dengan penggunaan nilai TOEFL.

Kedua, nilai TOEFL banyak digunakan oleh mahasiswa untuk berbagai keperluan semisal syarat-syarat untuk mengikuti program hibah, mengikuti yudisium atau wisuda, melamar pekerjaan, dan sebagainya. Kebanyakan keperluankeperluan itu menuntut mahasiswa untuk memiliki nilai TOEFL tertentu. Oleh karena itu, mahasiswa perlu meningkatkan nilai TOEFL mereka melalui berbagai program kursus atau pelatihan, baik yang dibiayai oleh lembaga maupun yang dibiayai sendiri. Usaha peningkatan nilai sebaiknya dilakukan sedini mungkin, tidak harus menunggu ketika kebutuhan datang. Untuk itu, diperlukan kesadaran, motivasi, dan ketelatenan mahasiswa.

Ketiga, salah satu kegunaan nilai TOEFL MABA adalah untuk menentukan tingkat masukan (input) dalam pelatihanpelatihan bahasa untuk mahasiswa. Selama ini, pembagian kelas dalam program pelatihan didasarkan pada nilai pre-tes yang memerlukan waktu, tenaga, dan biaya. Sebenarnya, hasil TOEFL MABA dapat digunakan untuk menempatkan mahasiswa peserta pelatihan dalam kelas-kelas yang sesuai dengan tingkat penguasaan bahasa Inggris mereka. Paling tidak, nilai TOEFL MABA ini dapat 
digunakan sebagai pre-survey terhadap tingkat profisiensi bahasa Inggris mahasiswa. Misalnya, Untuk mahasiswa baru prodi Sastra Inggris dan Pendidikan Bahasa Inggris, penempatan dapat langsung ditujukan ke kelas Intermediate, atau bahkan Pre-advanced, mengingat bahwa nilai TOEFL mereka sudah rata-rata 400 ke atas.

Keempat, pembelajaran MKU bahasa Inggris juga dapat menggunakan hasil TOEFLMABA sebagai salah satu masuk-an berupa karakteristik mahasiswa. Masukan ini digunakan dalam pemilihan fokus, kegiatan, dan bahan pembelajaran dalam MKU. Untuk mahasiswa MIPA dan FBS, misalnya, pembelajaran Reading dapat menggunakan teknik-teknik yang lebih otonomik, yakni pembelajaran yang bersifat mandiri. Ini mengingat bahwa mahasiswa kedua fakultas ini cenderung memiliki keterampilan membaca yang cukup tinggi. Pembelajaran bahasa Inggris MKU selama ini cenderung bersifat umum dengan bahan instruksional yang sama bagi semua mahasiswa. Hal ini dapat mengakibatkan dampak yang kurang positif terhadap mahasiswa maupun dosen. Mereka cenderung kurang bersemangat dalam kelas-kelas MKU karena kegiatan dan bahan pembelajarannya kurang menantang dan kurang sesuai dengan kebutuhan siswa.

Kelima, hasil TOEFL MABA dapat digunakan sebagai data pendahuluan untuk perancangan program-program internasional. Dengan menggunakan data yang nyata ini, diharapkan bahwa pelaksanaan program-program internasional dapat berjalan dengan lancar. Banyak ditengarai bahwa program-program semacam ini berjalan dengan tersendatsendat karena tuntutan penguasaan bahasa Inggris tidak benar-benar dipenuhi. Akibatnya, di tengah jalan diadakanlah kegiatan-kegiatan susulan dengan tujuan untuk meningkatkan penguasaan bahasa Inggris mahasiswa. Ini dapat menjadi indikasi bahwa perencanaan program kurang didasarkan pada data yang nyata, dalam hal ini penguasaan bahasa Inggris mahasiswa, misalnya. Apabila hasil TOEFL MABA digunakan sebagai data pendahuluan, dapat dipastikan bahwa perencanaan dan pelaksanaan programprogram internasional akan berjalan dengan lebih lancar.

Keenam, dalam Kurikulum mendatang, disyaratkan bahwa mahasiswa memiliki nilai TOEFL 400 untuk dapat dinyatakan lulus jenjang pendidikan S-1 UNY. Di satu pihak, persyaratan ini merupakan hal yang logis dan tepat. Pertama, untuk jenjang pascasarjana, UNY telah menetapkan nilai 425 bagi mahasiswa S-2 dan 475 untuk mahasiswa S-3 untuk lulus dan mendapatkan ijazah. Dengan demikian, angka 400 untuk mahasiswa S-1 adalah sesuatu yang logis. Kedua, persyaratan nilai ini dapat memberikan jaminan yang cukup kuat bahwa lulusan UNY memiliki kualitas penguasaan bahasa Inggris yang cukup tinggi (Bandingkan dengan informasi yang telah dikemukakan di depan bahwa nilai rerata siswa SMA terpilih di seluruh Indonesia adalah 418). Namun, di lain pihak, persyaratan ini juga bersifat kurang proporsional. Jalan tengah yang dapat digunakan adalah menentukan besaran nilai kelulusan berdasarkan besaran nilai TOEFL MABA. Misalnya, untuk mahasiswa prodi Sastra Inggris, Pendidikan Bahasa Inggris, Pendidikan Akuntansi, dan Informatika, persyaratan kelulusan adalah 450. Untuk mahasiswa prodi lain, persyaratan kelulusan dapat diturunkan secara proporsional menjadi 425, 400 dan 375.

\section{SIMPULAN}

Penguasaan bahasa Inggris mahasiswa baru UNY tahun 2005-2009 pada parameter TOEFL-Like adalah 367 dan deviasi standar 50,65. Secara umum, mahasiswa baru UNY dapat dikategorikan sebagai menguasai bahasa Inggris dalam tingkat intermediate atau menengah. Pemerolehan nilai TOEFL dari tahun ke 
tahun cukup fluktuatif. Walaupun ada kecenderungan untuk mengarah naik, fluktuasi dari tahun ke tahun sukar untuk dapat diprediksi. Mahasiswa baru Tahun Akademik 2005-2006, misalnya, terlihat paling homogen sedangkan mahasiswa baru Tahun Akademik 2006-2007 terlihat paling heterogen. Dalam hal nilai masing-masing komponen bahasa, Listening terlihat memiliki keajegan yang cukup tinggi (berkisar pada 33,75\%). Pemerolehan nilai untuk Structure cukup fluktuatif (berkisar pada 31,25\%); demikian pula untuk (berkisar pada 36,8\%). Pada tingkat Fakultas, FMIPA menduduki ranking tertinggi $(378,81)$; disusul bertutur-turut oleh FISE $(372,83)$, FT $(367,18)$, FBS $(363,83)$, dan FIP $(363,77)$, dan FIK $(356,44)$. Pada tingkat Program Studi, dua Prodi (Sastra Inggris, Pendidikan Bahasa Inggris) memiliki rerata TOEFL 400 atau lebih (Pre-advanced), 15 Prodi (Informatika, Pendidikan Matematika, Pendidikan IPS, Pendidikan Akuntansi, Administrasi Negara, Manajemen, Pendidikan Kimia, Akuntansi S1, Kimia, Pendidikan Bahasa Jerman, Pendidikan Fisika, Matematika, Sipil dan Perencanaan, Pendidikan Teknik Elektro, dan Pendidikan Biologi) memiliki rerata TOEFL 375 (Intermediate), dan sisanya masih di bawah penguasaan bahasa tingkat Intermediate.

Sebagai tindak lanjut TOEFL MABA, penyelenggaraan test harus diikuti dengan program-program kegiatan akademik. Hasil test harus dimanfaatkan sedemikian rupa sehingga program-program akademik dapat berjalan dengan lancar dan membuahkan hasil yang diharapkan. Beberapa kemungkinan pemanfaatan hasil TOEFL MABA dapat dilihat dalam seleksi mahasiswa untuk berbagai program

Untuk penyelenggaraan pelatihan bahasa Inggris, misalnya, hasil TOEFL MABA dapat digunakan sebagai dasar untuk penempatan mahasiswa ke kelas-kelas yang sesuai dengan tingkat penguasaan bahasa Inggris mereka. Perlu diketahui bahwa, selama ini, hasil TOEFL MABA belum banyak dimanfaatkan oleh lembaga, baik dari tingkat universitas hingga tingkat prodi, untuk tujuan perencanaan dan pengembangan akademik terutama yang berhubungan dengan mahasiswa. Oleh karena itu, mahasiswa perlu meningkatkan nilai TOEFL mereka melalui berbagai program kursus atau pelatihan, baik yang dibiayai oleh lembaga maupun yang dibiayai sendiri. Usaha peningkatan nilai sebaiknya dilakukan sedini mungkin, tidak harus menunggu ketika kebutuhan datang. Untuk itu, diperlukan kesadaran, motivasi, dan ketelatenan mahasiswa. Makin tenang dan telaten mahasiswa mengikuti pelatihan, makin berhasil pula usahanya untuk meningkatkan nilai.

Nilai TOEFL mahasiswa baru UNY dapat digunakan untuk menentukan berbagai kebijakan baik pada tingkat Universitas, Fakultas, maupun Program Studi. Untuk pelatihan bahasa Inggris, misalnya, bahan maupun kegiatan pelatihan dapat diolah sedemikian rupa sehingga sesuai dengan tingkat profisiensi mahasiswa dalam Listening, Structure, dan Reading. Pembelajaran MKU bahasa Inggris juga dapat menggunakan hasil TOEFL MABA sebagai salah satu masukan yang dapat digunakan dalam pemilihan fokus, kegiatan, dan bahan pembelajaran dalam MKU. Program-program internasional dapat memanfaatkan hasil TOEFL MABA, baik nilai rerata umum maupun nilai rerata per komponen bahasa, untuk merencanakan dan mengelola berbagai kegiatan sehingga kegiatan-kegiatan tersebut dapat berjalan dengan lebih terarah dan berhasilguna. Demikian pula, nilai TOEFL MABA dapat digunakan sebagai bahan pertimbangan untuk menentukan kualifikasi lulusan UNY berdasarkan tingkat profisiensi bahasa Inggris.

\section{SARAN}

Dari pembahasan hasil penelitian dikemukakan tujuh butir saran yang merupakan tindak lanjut dari pelaksanaan TOEFL MABA. Ketujuh saran berhubung- 
an dengan langkah-langkah yang dapat dilakukan oleh lembaga, dari tingkat universitas hingga tingkat program studi, dan penelitian lanjutan yang mungkin dilakukan untuk menggali lebih dalam informasi-informasi yang bisa didapat dari TOEFL MABA.

Pertama, penyelenggaraan TOEFL MABA UNY masih patut untuk dilaksanakan. Ini mengingat bahwa fluktuasi pemerolehan nilai pada Prodi-prodi cukup besar dari tahun ke tahun. Dapat dikatakan bahwa untuk tahun tertentu, mahasiswa memiliki karakteristik tertentu sehubungan dengan profisiensi bahasa Inggris. Dengan memiliki data nilai TOEFL mahasiswa tiap tahun akademik, pengelolala Prodi dapat memiliki data yang kongkrit yang dapat digunakan dalam program-program pengembangan Prodi.

Kedua, seleksi penerimaan mahasiswa baru UNY dapat memanfaatkan nilai TOEFL atau TOEFL-Like calon mahasiswa sebagai indikator profisiensi bahasa Inggris calon mahasiswa. TOEFL ini haruslah yang dikeluarkan oleh lembaga pelayanan bahasa yang sudah diakui kualitas dan integritasnya oleh umum. Makin tinggi nilai TOEFL calon mahasiswa, makin besarlah harga kriteria yang digunakan dalam penerimaan mahasiswa dan makin tinggi kualitas mahasiswa baru dalam hal penguasaan bahasa Inggris. Sebagai gambaran umum, nilai TOEFL 375 dapat ditentukan sebagai batas minimal untuk calon mahasiswa yang menggunakan nilai TOEFL sebagai syarat diterima sebagai mahasiswa baru UNY.

Ketiga, peningkatan nilai TOEFL sebagai indikator peningkatan penguasaan bahasa Inggris mahasiswa perlu dilakukan secara rutin dan berkelanjutan melalui pelatihan-pelatihan oleh lembaga atau oleh mahasiswa secara perseorangan. Perancangan bahan dan kegiatan kegiatan pelatihan haruslah menggunakan nilai TOEFL MABA agar dapat memberikan hasil pembelajaran yang optimal. Selain pelatihan TOEFL, pelatihan keterampilan berbahasa yang berupa berbicara, menyimak, membaca, dan menulis juga perlu diselenggarakan dengan baik. Pelatihan ini ditujukan untuk meningkatkan keterampilan komunikatif mahasiswa untuk mendukung mahasiswa dalam berbagai kegiatan yang menuntut penggunaan bahasa Inggris seperti berbagai lomba dan kompetisi, baik yang bersifat akademik maupun non-akademik.

Keempat, informasi yang didapat dari TOEFL MABA perlu ditindaklanjuti oleh pengelola lembaga dari tingkat universitas sampai program studi. Karakteristik profisiensi mahasiswa perlu dicermati. Dengan menggunakan statistik sederhana, misalnya, pengelola akan mendapatkan gambaran rinci mengenai penguasaan bahasa Inggris mahasiswa. Informasi TOEFL MABA perlu disimpan dengan rapi dan tertib dalam arsip-arsip sedemikian rupa sehingga mudah untuk diakses guna berbagai keperluan, termasuk perancangan dan pelaksanaan program-program internasional.

Kelima, pembelajaran MKU Bahasa Inggris seyogyanya menggunakan hasil TOEFL MABA sebagai salah satu masukan berupa karakteristik mahasiswa. Masukan ini digunakan dalam pemilihan fokus, kegiatan, dan bahan pembelajaran, sehingga pembelajaran bahasa Inggris MKU menjadi lebih bermakna dan berguna bagi mahasiswa. Dengan upaya semacam ini diharapkan bahwa mahasiswa dapat memiliki minat dan motivasi belajar yang tinggi. Pada akhirnya, pembelajaran bahasa Inggris MKU tidak hanya sekedar formalitas kurikuler saja, tetapi pembelajaran yang memberi manfaat nyata bagi penguasaan bahasa Inggris mahasiswa.

Keenam, penerapan peraturan akademik yang mensyaratkan nilai tertentu bagi mahasiswa untuk lulus jenjang S-1 seyogyanya dilakukan dengan bijaksana. Dalam tarik menarik antara kualitas dan kuantitas, pengelola seyogyanya menempuh jalan tengah. Di satu pihak, tuntutan 
nilai TOEFL tinggi akan menjadi salah satu indikator kualitas lulusan UNY. Di lain pihak, menghindari peraturan akademik yang akan menjadi kendala bagi siswa untuk dinyatakan lulus adalah langkah yang bijaksana. Untuk itu, nilai antara 375 sampai 450 dapat digunakan sebagai ancar-ancar untuk persyaratan kelulusan sesuai dengan karakteristik mahasiswa pada tingkat fakultas atau prodi.

Ketujuh, penelitian lanjutan yang berhubungan dengan TOEFL MABA perlu dilakukan untuk mendapatkan informasi lebih dalam mengenai profisiensi bahasa Inggris mahasiswa. Salah satu topik yang dapat dikembangkan adalah yang berhubungan dengan faktor-faktor yang berpengaruh terhadap pencapaian nilai TOEFL mahasiswa seperti jenis kelamin, sekolah asal, tempat tinggal asal, pelatihan bahasa Inggris di luar sekolah, dan sebagainya. Topik lain yang menarik untuk diteliti adalah pencapaian nilai TOEFL lulusan. Adanya kombinasi nilai TOEFL mahasiswa baru dan lulusan akan memberikan informasi yang lebih lengkap mengenai karakteristik mahasiswa pada tingkat universitas, fakultas, dan program studi.

\section{UCAPAN TERIMA KASIH}

Peneliti mengucapkan terima kasih kepada BPP FBS yang telah memfasilitasi peneliti untuk melakukan studi ini. Peneliti juga mengucapkan terima kasih kepada kelompok mahasiswa yang telah membantu peneliti dalam analisis data melalui program SPSSx.

\section{DAFTAR PUSTAKA}

Alave., K. L. 2006. Firmed urge to test English proficiency. Business World Manila, Nov., 2006.

Antara. 2008. Jakarta, December 5, 2008.

Antara. 2004. Jakarta, March 5, 2008.

Antara. 2003. Jakarta, October 11, 28.

Creswell, J. W. 2008. Educational Research: Planning, Conducting, and Evaluating Quantitative and Qualitative Research. Upper Saddle River, N. J.: Pearson Education, Inc.

Departemen Pendidikan Nasional. (2009). Laporan Program Rintisan Uji Kompetensi Bahasa Inggris (Test of English Proficiency, TOEP) untuk Peserta Didik di SMA. Jakarta: Depdiknas, Direktorat Jenderal Manajemen Pendidikan Dasar dan Menengah.

ETS. 2009. The Official Guide to the New TOEFL (International Edition). Boston: McGraw-Hill Education.

Johnson, B. \& Christensen, L. 2008. Educational Research: Quantitative, Qualitative, and Mixed Approaches (3rd Ed.). Thousand Oaks, Cal.: Sage Publications, Inc.

Roemer, A. 2002. A David of TOEFL's Goliath. TESOL Conference. Salt Lake City, UT.

Simner, M. L. and Mitchell, J. B. 2000. Use of the TOEFL as an Admission Requirement to Canadian University. Canadian Journal of School Psychology, 22.

Tucker, J. and van Bemmet, E. 2002. IELTS to Success: Preparation Tips and Practice Test. (2nd Ed.). Sydney: John Wiley \& Sons Australia, Ltd.

Weir, C. J. 2005. Language Testing and Validation. New York: Palgrave MacMillan. 